Document downloaded from:

http://hdl.handle.net/10251/61728

This paper must be cited as:

Igual Ramo, M.; Ramires, S.; Mosquera, LH.; Martínez Navarrete, N. (2014). Optimization of spray-drying conditions for lulo (Solanum quitoense L.) pulp. Powder Technology. 256:233238. doi:10.1016/j.powtec.2014.02.003.

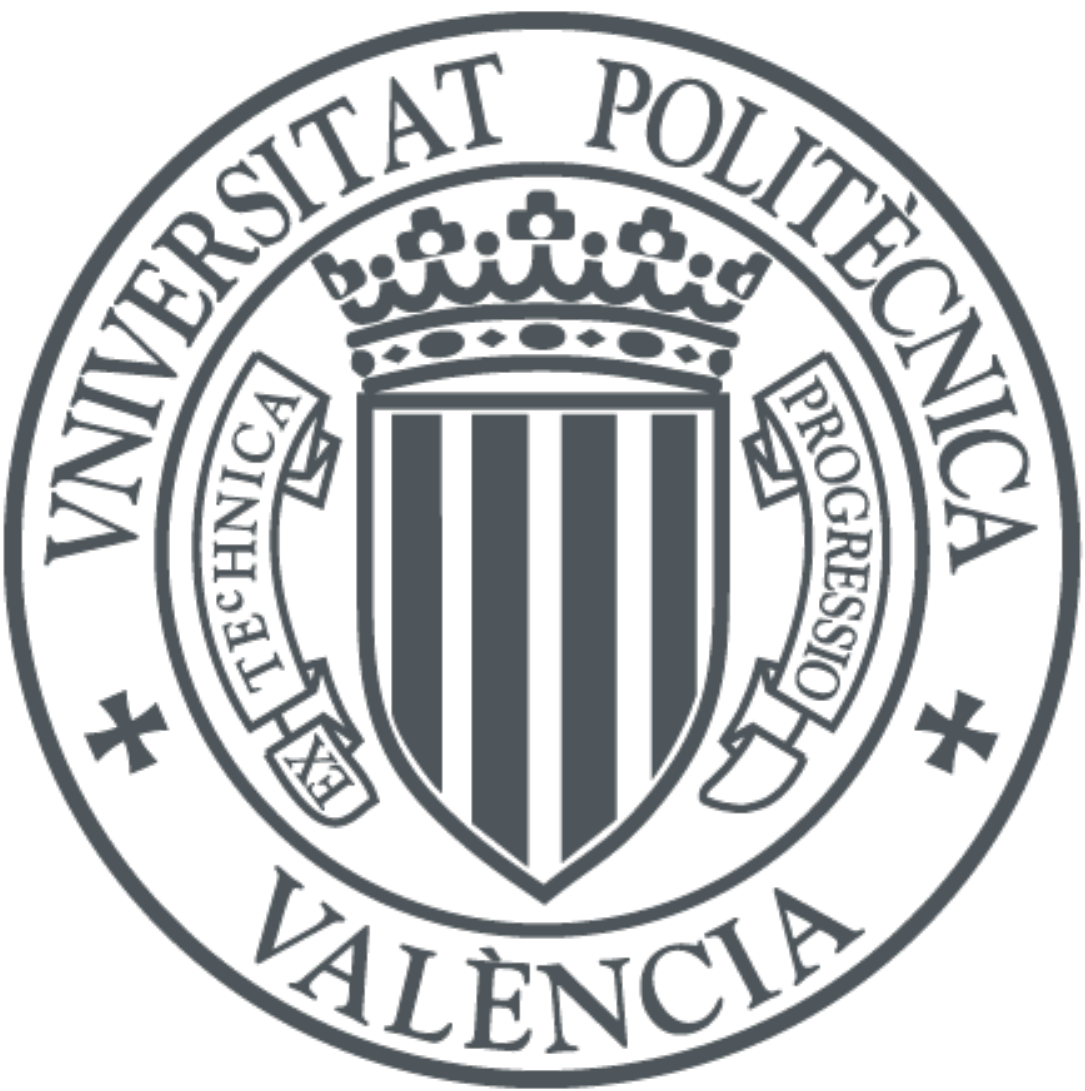

The final publication is available at

http://dx.doi.org/10.1016/j.powtec.2014.02.003

Copyright Elsevier

Additional Information 


\section{Optimization of spray drying conditions for lulo (Solanum quitoense L.) pulp}

Igual, $\mathrm{M}^{\mathrm{a}}$., Ramires, $\mathrm{S}^{\mathrm{b}}$., Mosquera. L. $\mathrm{H}^{\mathrm{c}}$., Martínez-Navarrete, $\mathrm{N}^{\mathrm{a}, *}$

\section{Abstract}

11 The spray drying of lulo was optimized by using the central composite design of the response surface methodology, to study the effect of inlet air temperature $\left(120-180^{\circ} \mathrm{C}\right)$,

13 arabic gum concentration $(0-10 \% \mathrm{w} / \mathrm{w})$, and maltodextrin DE16.5-19.5 concentration (0-

$1410 \% \mathrm{w} / \mathrm{w}$ ) on some product and process aspects. Arabic gum and maltodextrin, more than

15 inlet air temperature, improved the product yield, reduced the hygroscopicity and the water

16 content of the obtained powder, and contributed to the retention of its nutritive and

17 functional properties through an increase in ascorbic acid, vitamin $\mathrm{C}$, total phenol and total

18 flavonoid content and antioxidant capacity. Significant $(p<0.05)$ response surface models

19 were obtained in every case, with the linear terms of solute concentration being the factors

20 that affected the response variables most significantly. The overall optimum spray drying

21 conditions for obtaining lulo powder were $125^{\circ} \mathrm{C}$ inlet air temperature, $3 \%(\mathrm{w} / \mathrm{w})$ arabic 22 gum, and 13.4\% (w/w) maltodextrin DE16.5-19.5.

\footnotetext{
* Corresponding author: Tel.: +34 96 3879362; fax: +34 9638773 69. E-mail address: nmartin@tal.upv.es (Martínez- Navarrete, N).
} 
24 Keywords: lulo powder, functional value, hygroscopicity, vitamin C, antioxidant activity, 25 phenolic compounds

\section{1. Introduction}

28 Lulo (Solanum quitoense L.) is cultivated on a very small scale and, in local areas, it is put

29 to traditional uses due to its highly nutritive value and/or medicinal properties [1]. Lulo, also 30 known as "naranjilla" belongs to the huge Solanaceae family [2]. This 1-2.5 $\mathrm{m}$ high 31 shrubby perennial is native to the Andes. The geographical distribution of Solanum 32 quitoense stretches from Venezuela to Peru. It is generally cultivated at a height of 33 between 1,000 and $1,900 \mathrm{~m}$ above sea level $[3,4]$. The naranjilla plant produces a 34 spherical fruit with a diameter that ranges from 3 to $8 \mathrm{~cm}$ [5]. The skin (exocarp) is orange 35 and it is usually covered with short, prickly, stiff hairs (or "spines") that easily rub off. The 36 skin is peeled and discarded in food preparation. The fruit's internal structure is similar to 37 that of the tomato: the yellow-green flesh (mesocarp and endocarp) forms four 38 compartments separated by membranous partitions and filled with translucent green or 39 yellowish pulp, very juicy and acid [6]. The naranjilla fruit is rarely eaten fresh mainly due 40 to its acidity, but is most commonly used to make flavored drinks, preserves and desserts.

41 The fresh juice is also processed into frozen concentrates and can be fermented to make

42 wine $[5,6]$. The fruit appears to have considerable nutritional potential due to its high 43 content in vitamins, proteins and minerals [6, 7].

44 Spray drying is a well-established and widely used method for transforming a wide range 45 of liquid food products into powder form. The process involves spraying finely atomized 46 solutions into a chamber where hot dry air rapidly evaporates the solution leaving the 47 spray-dried particles. Spray-dried powders can be stored at room temperature for 48 prolonged periods without compromising the powder's stability [8]. Powders are cheaper to 49 transport and easier to handle in manufacturing plants. Spray-dried powders are 
economical to produce compared to other processes, such as freeze-drying [9]. Spray

51 drying has many applications, particularly in the food, pharmaceutical and agrochemical

52 industries [10-13]. The conversion of high value food materials, such as fruit and vegetable

53 extracts, into particulate form is not easy due to the presence of a high proportion of low

54 molecular weight sugars in their composition [13], which lead to the problem of stickiness

$55[14,15]$. The particles stick to one another, to the dryer and to cyclone walls and remain

56 there, forming thick wall deposits, while very little product comes out at the dryer's exit.

57 This might lead to low product yield and operating problems $[10,16]$. In general, the

58 stickiness causes considerable economic loss and limits the application of spray drying on

59 foods as well as on pharmaceutical materials [11, 17]. In order to reduce stickiness,

60 different solutes have been used as carriers and coating agents for the spray drying [18-

61 23]. Some examples of these are arabic gum, maltodextrins, starches, gelatin, methyl

62 cellulose, gum tragacanth, alginates, pectin, silicon dioxide, tricalcium phosphate, glycerol

63 monostearate and mixtures of some of them. Of these additives, maltodextrin offers a

64 good compromise between cost and effectiveness. It has been found that it contributes to

65 the retention of some food properties, such as nutrients, colour and flavour, during spray

66 drying and storage [14]. There are numerous reports on the spray drying of different fruits

67 with maltodextrin: aril fruit [24], cactus pear [14, 25, 26], watermelon [27], black carrot [28],

68 pineapple [29] and mango [30]. Nevertheless, arabic gum has been proved to be more

69 effective than maltodextrin at improving the handling of the borojó powder [31]. On the

70 other hand, the feed flow rate, the inlet and outlet air temperatures, atomizer speed, feed

71 concentration, feed temperature and inlet air flow rate are important factors that have to be

72 controlled in a spray drying process [32]. Among them, the inlet and/or outlet air

73 temperatures are the most effective factors in spray drying to be optimized [33]. The aim of

74 this work was to optimize the spray drying conditions of lulo (Solanum quitoense L.) pulp in

75 order to favour the process yield and to produce a stable powder with high nutritional and 
76 functional values. The inlet air temperature and maltodextrin and arabic gum concentration

77 were considered as the process variables.

\section{2. Materials and methods}

\section{2.1. Raw material}

82 This study was carried out with frozen lulo (Solanum quitoense L.) pulp supplied by Jota

83 Jota Alimentos Global S.L. (Valencia, Spain). Maltodextrin DE16.5-19.5 (MD) and arabic

84 gum (AG) added to the pulp were purchased from Sigma-Aldrich (USA).

86 2.2. Preparation of feed mixture and spray drying conditions

87 The frozen lulo pulp was thawed and mixed with a water solution containing MD and/or

88 AG. Solutes were added according to the generated experimental designobtained from the 89 response surface methodology (RSM) (Table 1) and commented on below. To incorporate 90 the solutes, a solution in water was previously prepared. The amount of each one of these

91 solutions was $200 \mathrm{~g}$, which were added to $200 \mathrm{~g}$ of lulo pulp. ${ }^{\circ}$ Brix of lulo pulp and the 92 mixture with the solute solution were measured. The mixture was stirred for 30 min until 93 homogeneity was reached. After that, ${ }^{\circ}$ Brix were measured with a refractometer at $20{ }^{\circ} \mathrm{C}$ 94 (Zeiss, ATAGO model NAR-3T, Japan), it was fed into a Büchi B-290 (Switzerland) mini 95 spray dryer with the following operating conditions: aspirator rate $90 \%\left(35 \mathrm{~m}^{3} / \mathrm{h}\right)$; 96 atomisation air rotameter $40 \mathrm{~mm}(473 \mathrm{~L} / \mathrm{h})$ with a co-current flow; pump rate $30 \%$ (9 $97 \mathrm{~mL} / \mathrm{min}$ ). Drying air inlet temperature was varied according to experimental design (Table

98 1). After the completion of the experiment and when the air inlet temperature fell below 50 $99 \stackrel{\circ}{ } \mathrm{C}$, the samples were collected from the product collection vessel. 
102 For this study, RSM was used to evaluate the effect of three process independent

103 variables on eleven response variables mainly related to the profitability of the process and

104 the quality of the powder. As independent variables, the inlet air temperature $\left(\mathrm{x}_{1}, 120-180\right.$

$\left.105{ }^{\circ} \mathrm{C}\right)$ and the concentration of arabic gum ( $\mathrm{x}_{2}, 0-10 \mathrm{~g} \mathrm{AG} / 100 \mathrm{~g}$ lulo pulp) and maltodextrin

106 (DE16.5-19.5) ( $\mathrm{x}_{3}, 0-10 \mathrm{~g} \mathrm{MD} / 100 \mathrm{~g}$ lulo pulp) were selected. The response variables taken

107 into consideration were those of outlet temperature $\left(Y_{1}\right)$, product yield $\left(Y_{2}\right)$, drying ratio

$108\left(\mathrm{Y}_{3}\right)$, productivity $\left(\mathrm{Y}_{4}\right)$, water content $\left(\mathrm{Y}_{5}\right)$, hygroscopicity $\left(\mathrm{Y}_{6}\right)$, ascorbic acid content $\left(\mathrm{Y}_{7}\right)$,

109 vitamin $\mathrm{C}$ content $\left(\mathrm{Y}_{8}\right)$, phenolic content $\left(\mathrm{Y}_{9}\right)$, flavonoid content $\left(\mathrm{Y}_{10}\right)$ and antioxidant

110 capacity $\left(\mathrm{Y}_{11}\right)$ of spray-dried lulo powder. Twenty-three experimental runs were generated

111 based on the corresponding rotatable and orthogonal central composite design (Table 1).

112 The experiments were randomized.

113

114 2.4. Analysis of response variables

$115 \mathrm{Y}_{2}$ was defined as the ratio of the mass of solutes present in the lulo powder obtained at 116 the end of each spray drying period, to the mass of solutes present in the mixture prior to 117 spray drying [34]. $\mathrm{Y}_{3}$ and $\mathrm{Y}_{4}$ were calculated for spray drying by using Cai and Corke [35] 118 but with a slight modification. The drying ratio and the productivity $(\mathrm{g} / \mathrm{h})$ were calculated by 119 equations (1) (powder solid content / feed solid content) and (2), respectively.

$$
\mathrm{Y}_{3}=\frac{\left(\mathrm{X}_{\mathrm{w}}^{\mathrm{i}}+1\right)}{\left(\mathrm{X}_{\mathrm{w}}^{\mathrm{f}}+1\right)}
$$

122 where $X_{w}{ }^{i}$ is the mixture feed moisture (dry basis), and $X_{w}{ }^{\dagger}$ is the powder moisture (dry 123 basis). 
125 where $\mathrm{Fr}$ is the feed rate $(\mathrm{g} / \mathrm{h})$, calculated from the mass of mixture feed $(\mathrm{g})$ and the 126 process time $(\mathrm{h})$.

127 The mass fraction of water $(\mathrm{g} / 100 \mathrm{~g})$ was obtained by vacuum drying the samples in a 128 vacuum oven (Vaciotem, J.P. Selecta, Spain) at $60^{\circ} \mathrm{C} \pm 1^{\circ} \mathrm{C}$ under a pressure of $<100$ $129 \mathrm{~mm} \mathrm{Hg}$ until constant weight. For hygroscopicity [35], samples (about $2 \mathrm{~g}$ in a Petri dish) of 130 each powder were placed at $25^{\circ} \mathrm{C}$ in an airtight plastic container containing a $\mathrm{Na}_{2} \mathrm{SO}_{4}$ 131 saturated solution $(81 \% \mathrm{RH})$ at the bottom. After one week, each sample was weighed and 132 hygroscopicity was expressed as $\mathrm{g}$ of water gained per $100 \mathrm{~g}$ dry solids.

133 Ascorbic acid (AA) and total vitamin C (ascorbic + dehydroascorbic acids) were 134 determined by HPLC (Jasco, Italy). To determine the ascorbic acid, a $1 \mathrm{~g}$ sample was 135 extracted with $9 \mathrm{~mL} 0.1 \%$ oxalic acid for $3 \mathrm{~min}$ [36] and immediately filtered through a 0.45 $136 \mu \mathrm{m}$ membrane filter before injection. The procedure employed to determine total vitamin $\mathrm{C}$ 137 was the reduction of dehydroascorbic acid to ascorbic acid, using DL-dithiothreitol as the 138 reductant reagent [37]. A $0.5 \mathrm{~mL}$ aliquot sample was taken to react with $2 \mathrm{~mL}$ of a $20 \mathrm{~g} / \mathrm{L}$ 139 dithiothreitol solution for $2 \mathrm{~h}$ at room temperature and in darkness. Afterwards, the same 140 procedure as that used for the ascorbic acid method was performed. The HPLC conditions 141 were: Ultrabase-C18, $5 \mu \mathrm{m}(4.6 \times 250 \mathrm{~mm})$ column (Análisis Vínicos, Spain); mobile phase $1420.1 \%$ oxalic acid, volume injection $20 \mu \mathrm{L}$, flow rate $1 \mathrm{~mL} / \mathrm{min}$, detection at $243 \mathrm{~nm}$ and at $14325^{\circ} \mathrm{C}$. AA standard solution (Panreac, Spain) was prepared.

144 The total quantity of phenols (TP) was analysed by using the method reported by Benzie \& 145 Strain [38] based on the Folin-Ciocalteu method, which involves the reduction of the 146 reagent by phenolic compounds with the concomitant formation of a blue complex. Total 147 flavonoids (TF) were measured spectrophotometrically, following the method described by 148 Djeridane et al., [39] based on the formation of a flavonoids-aluminium complex. For the 149 extraction of TP and TF, $35 \mathrm{~g}$ of the sample were homogenized (T25D Ultra-turrax, IKA, 150 Germany) for $5 \mathrm{~min}$ with $40 \mathrm{~mL}$ of methanol, $10 \mathrm{~mL}$ of $\mathrm{HCl}(6 \mathrm{~N})$ and $\mathrm{NaF}(2 \mathrm{mM})$ to 
151 prevent phenolic degradation caused by polyphenol oxidase action; the homogenate was

152 centrifuged at $10,000 \mathrm{rpm}, 10 \mathrm{~min}, 4^{\circ} \mathrm{C}$. For TP quantification, $15 \mathrm{~mL}$ of distilled water and

$1531.25 \mathrm{~mL}$ of Folin Ciocalteu reagent (Sigma-Aldrich, Germany) were added to $250 \mu \mathrm{L}$ of the

154 supernatant. The samples were mixed and allowed to stand for $8 \mathrm{~min}$ in darkness before

$1553.75 \mathrm{~mL}$ of $7.5 \%$ sodium carbonate aqueous solution was added. Water was added to

156 adjust the final volume to $25 \mathrm{~mL}$. Samples were allowed to stand for $2 \mathrm{~h}$ at room

157 temperature before absorbance was measured at $765 \mathrm{~nm}$ in a UV-visible

158 spectrophotometer (Thermo Electron Corporation, USA). The total phenolic content was

159 expressed as $\mathrm{mg}$ of gallic acid equivalents (GAE) per gram of sample, using a standard

160 curve range of $0-800 \mathrm{mg}$ of gallic acid (Sigma-Aldrich, Germany)/mL. For TF

161 quantification, $1 \mathrm{~mL}$ of the extract was mixed with $1 \mathrm{~mL}$ of $20 \mathrm{~g} / \mathrm{L} \mathrm{AlCl}_{3}$ methanolic solution.

162 After incubation at room temperature for $30 \mathrm{~min}$ in darkness, the absorbance of the

163 reaction mixture was measured at $430 \mathrm{~nm}$ using the aforementioned spectrophotometer.

164 The total content in flavonoids was expressed as mg of rutin equivalents (RE) per gram of

165 sample, using a standard curve range of 0-50 mg of rutin (Sigma-Aldrich, Germany)/L.

166 Antioxidant capacity (AOC) was assessed using the free radical scavenging activity of the

167 samples evaluated with the stable radical DPPH [37]. Briefly, the samples were

168 homogenized and centrifuged (Selecta Medifriger-BL, Spain) at 10,000 rpm for 10 min at 4

$169{ }^{\circ} \mathrm{C} .0 .1 \mathrm{~mL}$ of supernatant diluted in methanol was added to $3.9 \mathrm{~mL}$ of DPPH diluted in

170 methanol $\left(0.030 \mathrm{~g} / \mathrm{L}\right.$, Sigma-Aldrich, Germany). At $25^{\circ} \mathrm{C}$, the same spectrophotometer

171 mentioned before was used to measure the absorbance at $515 \mathrm{~nm}$ at $0.25 \mathrm{~min}$ intervals

172 until the reaction reached the steady state. Appropriately diluted samples were used on

173 the day of preparation. The percentage of DPPH was calculated following equation (3):

$$
\% \mathrm{DPPH}=\frac{\left(\mathrm{A}_{\text {control }}-\mathrm{A}_{\text {sample }}\right)}{\mathrm{A}_{\text {control }}} \times 100
$$


175 where $A_{\text {control }}$ is the absorbance of the control (initial time) and $A_{\text {sample }}$ the absorbance of the 176 sample at the steady state.

177 The final results were expressed as milimole trolox equivalents (TE) per 100 grams (mmol

$178 \mathrm{TE} / 100 \mathrm{~g}$ ) using a trolox calibration curve in the range 6.25-150 mM (Sigma-Aldrich, 179 Germany).

180 Every analysis of the $Y_{5}$ to $Y_{11}$ variables was carried out in triplicate. To characterize the 181 lulo pulp, the results of $Y_{7}$ to $Y_{11}$ were referred to $100 \mathrm{~g}$ of lulo pulp, while for the statistical 182 study, all of them were expressed as $\mathrm{mg}$ of each compound/100 $\mathrm{g}$ total lulo solids (TLS).

183 2.5. Statistical analysis

184 An analysis of variance and a regression surface analysis were conducted to fit a 185 regression relationship relating the experimental data to the independent variables. The 186 generalized polynomial model proposed for the prediction of the response variables as a 187 function of the independent variables was that given by equation (4):

$188 Y_{i}=\beta_{0}+\beta_{1} X_{1}+\beta_{2} X_{2}+\beta_{3} X_{3}+\beta_{11} x_{1}^{2}+\beta_{22} X_{2}^{2}+\beta_{33} X_{3}^{2}+\beta_{12} X_{1} X_{2}+\beta_{13} X_{1} X_{3}+\beta_{23} X_{2} X_{3}$

189 where $Y_{i}$ was the response value predicted by the model; $\beta_{0}$ was a constant; $\beta_{1}, \beta_{2}$, and $\beta_{3}$ 190 were the regression coefficients for the linear effects; $\beta_{11}, \beta_{22}$, and $\beta_{33}$ were those for the 191 quadratic effects; and $\beta_{12}, \beta_{13}$, and $\beta_{23}$ were those which included interaction effects. In this 192 model, $x_{1}, x_{2}$, and $x_{3}$ were the independent variables. Only the model terms found to be 193 statistically significant $(p<0.05)$ were included in the final reduced model. The terms which 194 were statistically non-significant $(p>0.05)$ were dropped from the initial models, and the 195 experimental data were refitted only to the significant $(p<0.05)$ independent variable effects 196 to obtain the final reduced model [40]. The fact that none of the selected final models 197 provided a significant lack of fit $(p>0.05)$ confirmed the suitability of the fitted model and 198 the non-significance of the Durbin-Watson statistic proved that there was no significant 199 autocorrelation in the residuals. The goodness of the fit of the final reduced models to the 
200 experimental data was evaluated from the adjusted coefficient of determination $\left(R^{2}\right.$ adj $)$ and

201 the standard error (SE) between the predicted and experimental values.

202 In the present study, for multiple response optimization, a response optimizer was used to 203 determine the combination of input variable settings that jointly optimized the response of 204 a set of variables. Through this optimization procedure, a combined level of the considered 205 spray drying independent variables was obtained to produce a spray-dried powder with the 206 most desirable powder properties (i.e., the highest content of ascorbic acid, vitamin C, 207 phenols flavonoids, the greatest antioxidant capacity, product yield and productivity and 208 the lowest outlet temperature, drying ratio, water content and hygroscopicity value).

209 The correlation between the antioxidant activity and every studied bioactive component 210 with a 95\% significance level was also analysed.

211 All statistical analyses were performed using Statgraphics Plus 5.1 [41].

\section{3. Results and Discussion}

214 3.1. Lulo (Solanum quitoense L.) pulp characterization

215 The mean values (with standard deviation in brackets) of $\mathrm{pH}$, Brix and water content of 216 lulo pulp were 3.29 (0.02), 8.5 (0.2) and 90.3 (1.2) g/100g, respectively. The soluble solids

217 consist of about $7.5 \mathrm{~g}$ sugars $/ 100 \mathrm{~g}$ lulo pulp and $1 \mathrm{~g}$ organic acids $/ 100 \mathrm{~g}$ lulo pulp (data not 218 shown). The non-dissolved material (1.2\%) is expected to be non-soluble carbohydrates 219 and some lipids. The total phenol content was 81.1 (1.6) mg GAE/ $100 \mathrm{~g}$ lulo pulp. Within 220 the group of phenolic compounds, the total flavonoid content in lulo pulp was $16.16(0.06)$ $221 \mathrm{mg} \mathrm{RE} / 100 \mathrm{~g}$. The vitamin C content was 120 (4) $\mathrm{mg} / 100 \mathrm{~g}$ and the value for ascorbic 222 acid was $61.4(1.5) \mathrm{mg} / 100 \mathrm{~g}$ ). These results coincide with the values obtained for 223 naranjilla by other authors $[1,6,42]$. 
226 The experimental results obtained for each response variable is shown in Table 1. The 227 final reduced models relating each response variable with the independent variables are 228 shown in Table 2. The results indicated the significance $(p<0.05)$ of the response surface 229 model, with high coefficients of determination values ranging from 0.74 to 0.97 . Thus, 230 more than $74 \%$ of the response variation may be accurately explained as a function of the 231 three independent spray drying variables selected. The adequacy of the response surface 232 equation was checked by the comparison of experimental and predicted values (data not 233 shown).

234 The outlet temperature ranged between 67 to $119 \stackrel{\circ}{\mathrm{C}}$ and it was mainly affected $(p<0.05)$ 235 by the inlet temperature with a positive linear and a negative quadratic effect. Moreover, a 236 negative quadratic effect of maltodextrin concentration on $Y_{1}$ was observed (Table 2). If 237 the results of $Y_{1}$ are observed (Table 1), it may be seen that the lower the inlet 238 temperature, the lower the outlet temperature. Lulo pulp contains sugars, which make the 239 spray drying process difficult, mainly due to the basic physical characteristics of the low 240 molecular weight sugars present in fruits, essentially sucrose, glucose and fructose. 241 Moreover, the presence of organic acids, such as tartaric, malic, and citric acid, also 242 contributes to the problem of stickiness in the powder [10]. In this work, it was extremely 243 difficult to obtain powder at the exit of the dryer in samples without added high molecular 244 weight solutes and large deposits were formed on the main chamber and cyclone walls. 245 For example, Table 1 shows the lower/lowest values of product yield for these samples 246 (runs 3 and 14). The addition of high molecular weight solutes, such as arabic gum and 247 maltodextrin, prior to spray drying was necessary in order to obtain powders. $Y_{2}$ was 248 positively affected by the concentration of arabic gum and maltodextrin. Despite there 249 being a negative quadratic effect of these solutes and of their interaction, an increase in 250 the solute concentration in lulo pulp improved the product yield in spray drying. 
251 The drying ratio decreased linearly when the concentration of any of the added solutes

252 rose, while the productivity mainly increased when there was a rise in the concentration of 253 arabic gum.

254 Generally, food powders with lower hygroscopicity and water content are considered a 255 good powdered product. Goula and Adamopoulos [43] suggested that adding maltodextrin 256 decreased powder hygroscopicity. In the present study, the hygroscopicity values of spray257 dried lulo powders showed values between 80 and $114 \%$, which decreased to $35-60 \%$ 258 when the considered solutes were added (Table 1). The hygroscopicity of lulo powder was 259 decreased $(p<0.05)$ due to an increase in the concentration of both arabic gum and 260 maltodextrin (Table 2). The lower degree of hygroscopicity of lulo powders when the 261 solutes were added could be related to the less hygroscopic nature of maltodextrin and 262 arabic gum. Similar observations were reported by other researchers [14, 22, 31, 35, 44]. 263 In general, the hygroscopicity values of samples with solutes were similar to those 264 obtained by Rodriguez-Hernandez et al. [14] and Cai and Corke [35] in their studies on 265 spray-dried cactus pear juice powder (36-49\%) and spray-dried Amaranthus powder (45$26650 \%$ ), respectively. The inlet air temperature also influenced the hygroscopicity of the 267 powder. Increasing the inlet temperature led to a lower degree of powder hygroscopicity. A 268 similar observation was reported by Goula and Adamopoulos [43, 44]; Moreira et al. [45], 269 and Jaya and Das [22]. However, in the final model, this factor had a less significant effect 270 than the incorporation of solutes (Table 2). Moreira et al. [45] reported that the higher 271 degree of hygroscopicity of the powders produced at lower temperatures seems to be 272 related to their higher water content. Water content has a prominent effect on powder 273 stability.

274 The water content of spray-dried lulo powders varied from $0.9 \%$ to $7 \%$. As shown in Table 275 1, the higher the inlet air temperature and arabic gum/maltodextrin concentration, the 276 lower the water content of the spray-dried lulo powder. At higher inlet air temperatures, 
277 there was a greater temperature gradient between the atomized feed and the drying air, 278 resulting in a higher rate of heat transfer for water evaporation, thus producing low-water 279 powders [23, 44]. The highest water content presented in Table 1 corresponds to lulo 280 without added solutes and spray-dried at lower inlet temperatures. The inlet temperature 281 effect was observed by León-Martínez et al. [46]; Kha et al. [24]; Quek et al. [27]; Ersus 282 and Yurdagel [28]; Rodríguez-Hernández et al. [14]; Chegini and Ghobadian [32]; Goula et 283 al. [47]; Cai and Corke [35] working with spray-dried nopal mucilage powder, gac fruit 284 powder, watermelon powder, black carrot powder, cactus pear juice powder, orange juice 285 powder, tomato powder, and amaranthus pigment powder, respectively. The water content 286 of lulo powder exhibited an inverse relationship with increasing arabic gum/maltodextrin 287 concentration, which was also reported by other authors [14, 22, 31, 35, 44]. Both the 288 water content and the hygroscopicity showed a positive interaction between both of the 289 solutes considered in the final model (table 2).

290 Maltodextrins and gums are also added during the production of food powders in order to 291 act as encapsulating or wall materials, contributing to keep the desired functional 292 properties in the finished product, such as stability against oxidation, ease of handling, 293 improved solubility, controlled release, and extended shelf-life [47, 48]. According to Qi 294 and $\mathrm{Xu}$ [49], high-DE maltodextrins show high reducing capacity, providing protection 295 against oxidation. The ability of maltodextrins to protect encapsulated products against 296 oxidation is attributed to their film-forming capacity and plastic properties, being also 297 largely used as wall materials due to a good compromise between cost and effectiveness, 298 being bland in flavor, and having a low viscosity at a high solid ratio. On the other hand, 299 arabic gum is the gum which is most commonly used as a flavour encapsulating material, 300 mainly due to its solubility, low viscosity, emulsification characteristics, and its good 301 retention of volatile compounds [50-52]. Reinnecius [53] found that combinations of 302 maltodextrin with arabic gum provided good protection against the oxidation of 
303 encapsulated aromas. In Table 1, it can be observed that samples with no solutes added

304 to feed prior to spray drying (runs 3 and 14) showed the lowest values of bioactive 305 compounds $\left(Y_{7}, Y_{8}, Y_{9}, Y_{10}\right.$ and $\left.Y_{11}\right)$. High weight molecular solutes reduced the powder's 306 stickiness and helped the retention of nutritive and functional properties. Moreover, in 307 samples 3 and 14 there was a significant $(p<0.05)$ decrease in the functional value when 308 the inlet temperature during spray drying was increased (Table 1). Quek et al. [27] 309 reported that the spray drying of watermelon juice at over $165^{\circ} \mathrm{C}$ led to inferior products 310 due to nutrient loss, and spray drying at temperatures of over $180^{\circ} \mathrm{C}$ were not suitable for

311 Amaranthus betacyanins pigments [35].

312 When high molecular weight solutes were added to lulo pulp prior to spray drying, a 313 temperature effect was also observed. For example, when spray drying of samples with $3145 \%$ arabic gum and $5 \%$ maltodextrin was carried out at $200 \stackrel{\circ}{C}$, a greater loss of bioactive 315 compounds was observed as compared to those spray-dried at 150 or $100{ }^{\circ} \mathrm{C}$ (Table 1 ). In 316 general, every studied bioactive compound and antioxidant capacity $\left(Y_{7}, Y_{8}, Y_{9}, Y_{10}, Y_{11}\right)$

317 was positively affected by an increase in solute concentration and a decrease in inlet 318 temperature (Table 2).

319 Pearson's statistical correlation analysis was used to establish correlations between the 320 antioxidant capacity and the studied bioactive compounds. The obtained results showed 321 that the most significant contribution to antioxidant capacity was provided by total flavonoid 322 content $(0.7762, p<0.05)$, followed by total phenol content $(0.7204, p<0.05)$, ascorbic acid $323(0.6980, \mathrm{p}<0.05)$ and vitamin $\mathrm{C}(0.6359, \mathrm{p}<0.05)$. In apricot [54] and grapefruit [55] the 324 most significant contribution to antioxidant capacity was provided by total phenol.

3263.3 Optimization procedure for predicting an optimum spray-dried lulo pulp

327 Spray-dried lulo powder could be considered an optimum product if the criteria applied to 328 achieve the optimization resulted in (1) the highest ascorbic acid, vitamin $\mathrm{C}$, total phenol 
329 and total flavonoid content and antioxidant capacity, as well as the greatest product yield

330 and productivity and (2) the lowest outlet temperature, drying ratio, water content and

331 hygroscopicity. Multiple response optimization suggested that the optimal conditions for

332 producing the best spray-dried lulo powder were reached by combining an inlet air

333 temperature of $125^{\circ} \mathrm{C}, 3 \%$ arabic gum, and $13.4 \%$ maltodextrin DE16.5-19.5. Under these

334 optimum conditions, the predicted responses for the obtained powder are: ascorbic acid =

$335225 \mathrm{mg} / 100 \mathrm{~g}$ lulo pulp solids, vitamin $\mathrm{C}=444 \mathrm{mg} / 100 \mathrm{~g}$ lulo pulp solids, total phenols = 957

$336 \mathrm{mg} / 100 \mathrm{~g}$ lulo pulp solids, total flavonoids $=128 \mathrm{mg} / 100 \mathrm{~g}$ lulo pulp solids, antioxidant

337 capacity $=115 \mathrm{mg} / 100 \mathrm{~g}$ lulo pulp solids, product yield $=35 \%$, productivity $=51 \mathrm{~g} / \mathrm{h}$, outlet

338 temperature $=78.6 \stackrel{\circ}{\circ}$, drying ratio $=7$, water content $=2.2 \mathrm{~g}$ water $/ 100 \mathrm{~g}$ and

339 hygroscopicity $=54 \mathrm{~g} / 100 \mathrm{~g}$.

\section{4. Conclusion}

342 The optimization of the spray drying conditions for the lulo pulp was successfully executed 343 using the central composite design of the RSM. The optimum powder was the one with a 344 high nutritive and functional value, low hygroscopicity and low water content. Significant 345 empirical equations $\left(R^{2}>0.74\right)$ have been developed for describing and predicting the 346 variation of each response variable studied. The concentrations of arabic gum and 347 maltodextrin were the factors that most significantly $(p<0.05)$ contributed to the increase in 348 the product yield and the decrease in both the hygroscopicity and the water content in 349 powder. These solutes also contributed to retain the nutritive and functional properties of 350 the fruit. The inlet temperature had the mildest effect on these variables. The multiple 351 response optimization predicted that the use of an inlet air temperature of $125{ }^{\circ} \mathrm{C}, 3 \%$ 352 arabic gum, and $13.4 \%$ maltodextrin DE16.5-19.5 provided the overall optimum 353 parameters for the spray drying of the lulo pulp. 


\section{Acknowledgment}

356 The authors thank the Universidad Politécnica de Valencia for the financial support given

357 throughout the Project ADSIDEO-COOPERACIÓN 2010 "Adaptación de procesos de 358 secado para favorecer la comercialización de super frutas de origen colombiano".

References

361 1. Gancel, A.L.; Alter, P.; Dhuique-Mayer, C; Ruales, J.; Vaillant, F. Identifying 362 carotenoids and phenolic compounds in naranjilla (Solanum quitoense Lam. var. 363 puyo hybrid), an andean fruit. J. Agric Food Chem 56 (2008) 11890-11899

364 2. Heiser, C. B.; Anderson, G. "New" Solanums. Perspectives on new crops and new use 365 Janick, J., Ed.; ASHS Press: Alexandria, VA, 1999, 379-384.

366 3. Heiser, C. B. The relationships of the naranjilla, Solanum quitoense. Biotropica, 1972, 4 $367 \quad 77-84$.

368 4. Dennis, F. G. J.; Herner, R. C. Naranjilla: a potential cash crop for the small farmer in 369 Latin America. Acta Hortic 158 (1985) 475-481

370 5. National Research Council. Naranjilla (Lulo). Lost crops of the Incas: Little known plants 371 of the Andes with promise of the world cultivation. National Academy Press: $372 \quad$ Washington, 1989, 267-275.

373 6. Morton, J. (1987). Naranjilla. Fruits of warm climates. Morton, J. F., Ed.; Miami, F.L, $374 \quad 1987,425-428$.

375 7. Griffiths, F. P. Processing procedure to retain Vitamin C in Naranjilla, Solanum 376 quitoense, products. J. Rio Grande Valley Hortic Soc 19 (1965) 33-36.

377 8. Jayasundera, M.; Adhikari, B.; Adhikari, R.; Aldred, P. The effects of proteins and low 378 molecular weight surfactants on spray drying of model sugar-rich foods: Powder $379 \quad$ production and characterisation. J Food Eng 104 (2011) 259-271 
9. Knorr, D. Technology aspects related to microorganisms in functional foods. Trends Food Sci Technol 9 (1998) 295-306

10. Bhandari, B.R.; Datta, N.; Howes, T. Problems associated with spray drying of sugarrich foods. Drying Technol 15 (1997) 671-684

11. Maa, Y. F.; Nguyen, P. A. T.; Hsu, S. W. Spray drying of air-liquid interface sensitive recombinant human growth hormone. J Pharm Pharm Sci 87(2) (1998) 152-159

12. Vega, C.; Goff, H. D.; Roos, Y. H. Spray drying of high-sucrose dairy emulsions: Feasibility and physicochemical properties. J Food Sci 70 (2005) 244-251

13. Adhikari, B.; Howes, T.; Shrestha, A. K.; Bhandari, B. R. Development of stickiness of whey protein isolate and lactose droplets during convective drying. Chem Eng Process 46 (2007) 420-428

14. Rodríguez-Hernández, G. R.; Gonzalez-Garcia, R.; Grajales-Lagunes, A.; RuizCabrera, M. A.; Abud-Archila, M. Spray-drying of cactus pear juice (Opuntia streptacantha): effect on the physicochemical properties of powder and reconstituted product. Drying Technol 23(4) (2005) 955-973.

15. Roustapour, O.R.; Hosseinalipour, M.; Ghobadian, B. An experimental investigation of lime juice drying in a pilot plant spray dryer. Drying Technol 24 (2006) 181-188

16. De Oliveira, M.A.; Maia, G.A.; De Figueiredo, R.W.; De Souza, A.C.R.; De Brito, E.S.; De Azeredo, H.M.C. Addition of cashew tree gum to maltodextrin-based carriers for spray drying of cashew apple juice. International J Food Sci Tech 44 (2009) 641-645

17. Boonyai, P.; Bhandari, B; Howes, T. Stickiness measurement techniques for food powders: A review. Powder Technol 145 (2004) 34-46

18. Glicksman M. Gum Technology in the Food Industry. Food Science \& Technology A Series of Monographs. Academic Press, Inc., New York, NY, 1969.

19. Revie, G. N.; Thomas, B. R. J. Powdered flavors offer many advantages. Food Manufacture 37(1) (1972) 40-41 
20. Main, J.H.; Clydesdale, F.M.; Francis, F.J. Spray drying anthocyanin concentrates for use as food colorants. J Food Sci 43 (1978) 1693-1694, 1697

21. Francis FJ. Handbook of Food Colorant Patents. Food \& Nutrition Press, Inc., Trumbull, Conn, 1986, 14-19.

22. Jaya, S.; Das, H. Accelerated storage, shelf life and colour of mango powder. J Food Process Preserv 29 (2005) 45-62.

23. Tonon, R.V.; Brabet, C.; Pallet, D.; Brat, P.; Hubinger, M.D. Physicochemical and morphological characterisation of ac ai powder produced with different carrier agents. International J Food Sci Tech 44 (2009)1950-1958

24. Kha, T. C.; Nguyen, M. H.;Roach, P. D. Effects of spray drying conditions on the physicochemical and antioxidant properties of the Gac (Momordica cochinchinensis) fruit aril powder. J Food Eng, 98 (2010) 385-392

25. Moßhammer, M. R.; Stintzing, F. C.; Carle, R. Evaluation of different methods for the production of juice concentrates and fruit powders from cactus pear. Innov Food Sci Emerg Technol 7(4) (2006) 275-287

26. Obon, J. M.; Castellar, M. R.; Alacid, M.; Fernández-López, J. A. Production of a redpurple food colorant from Opuntia stricta fruits by spray drying and its application in food model systems. J Food Eng 90 (2009) 471-479

27. Quek, S. Y.; Chok, N. K.; Swedlund, P. The physicochemical properties of spray-dried watermelon powders. Chem Eng Process 46 (2007) 386-392.

28. Ersus, S.; Yurdagel, U. Microencapsulation of anthocyanin pigments of black carrot (Daucuscarota L.) by spray drier. J Food Eng 80 (2007) 805-812

29. Abadio, F. D. B.; Domingues, A. M.; Borges, S. V.; Oliveira, V. M. Physical properties of powdered pineapple (Ananas comosus) juice-effect of maltdextrin concentration and atomization speed. J Food Eng 64 (2004) 285-287 
431 30. Cano-Chauca, M.; Stringheta, P. C.; Ramos, A. M.;Cal-Vidal, J. Effect of the carriers 432 on the microstructure of mango powder obtained by spray drying and its functional 433 characterization. Innov Food Sci Emerg Technol 6 (2005) 420-428

434 31. Mosquera, L.H.; Moraga, G; Martínez-Navarrete, N. Critical water activity and critical water content of freeze-dried strawberry powder as affected by maltodextrin and arabic gum. Food Res Int 47 (2012) 201-206

32. Chegini, G. R.; Ghobadian, B. Effect of spray-drying conditions on physical properties of orange juice powder. Drying Technol 23(3) (2005) 657-668

33. Liu, Z.; Zhou, J.; Zeng, Y.; Ouyang, X. The enhancement and encapsulation of Agaricus bisporus flavor. J Food Eng 65 (2004) 391-396

34. Vandir, H.; Yasar, M. Optimisation of pomegranate (Punica Granatum L.) juice spraydrying as affected by temperature and maltodextrin content. Int J Food Sci Technol 47 (2012) 167-176

444 35. Cai, Y.Z.; Corke, H. Production and properties of spraydried amarantus betacyanin 445 pigments. J Food Sci 65 (2000) 1248-1252

36. Xu, G.; Liu, D.; Chen, J.; Ye, X.; Ma, Y.; Shi, J. Juice components and antioxidant capacity of citrus varieties cultivated in China. Food Chem 106 (2008) 545-551

448 37. Sánchez-Moreno, C.; Plaza, L;, De Ancos, B.; Cano, M. P. Quantitative bioactive compounds assessment and their relative contribution to the antioxidant capacity of

451 38. Benzie, I. F. F.; Strain, J. J. Ferric reducing/antioxidant power assay: Direct measure 452 of total antioxidant activity of biological fluids and modified version for simultaneous 453 measurement of total antioxidant power and ascorbic acid concentration. Methods 454 Enzymol 299 (1999) 15-27 
39. Djeridane, A.; Yousfi, M.; Nadjemi, B.; Boutassouna, D.; Stocker, P.; Vidal, N. Antioxidant activity of some Algerian medicinal plants extracts containing phenolic compounds. Food Chem 97(4) (2006) 654-660

40. Mirhosseini, H.; Tan, C. P.; Hamid, N. S. A.; Yusof, S.; Chern, B. H. Characterization of the influence of main emulsion components on the physicochemical properties of orange beverage emulsion using response surface methodology. Food Hydrocoll 23 (2009) 271-280

41. Statgraphics Plus 5.1. for Windows (2000). Statistical Graphics Corporation. Virginia, USA: StatPoint, Inc.

42. Vasco C.; Ruales J.; Kamal-Eldin A. Total phenolic compounds and antioxidant capacities of major fruits from Ecuador. Food Chem 111(4) (2008) 816-823

43. Goula, A. M.; Adamopoulos, K. G. Effect of maltodextrin addition during spray drying of tomato pulp in dehumidified air: II. Powder properties. Drying Technol 26(6) (2008) 726-737

44. Goula, A. M.; Adamopoulos, K. G. A new technique for spray drying orange juice concentrate. Innov Food Sci Emerg Technol 11 (2010) 342-351

45. Moreira, G. E. G.; Costa, M. G. M.; de Souza, A. C. R.; de Brito, E. S.; de Medeiros, M. F. D.; de Azeredo, H. M. C. Physical properties of spray dried acerola pomace extract as affected by temperature and drying aids. Lebenson Wiss Technol 42 (2009) 641-645

46. León-Martínez, F. M.; Méndez-Lagunas, L. L.; Rodríguez-Ramírez, J. Spray drying of nopal mucilage (Opuntia ficus-indica): Effects on powder properties and characterization. Carbohydr Polym 81 (2010) 864-870

47. Claude, J.; Ubbink, J. Thermal degradation of carbohydrate polymers in amorphous states: A physical study including colorimetry. Food Chem 96 (2006) 402 -410 
47. Goula, A. M.; Adamopoulos, K. G.; Kazakis, N. A. Influence of spray drying conditions on tomato powder properties. Drying Technol 22(5) (2004) 1129-1151.

48. Pérez-Alonso, C.; Beristain, C.I.; Lobato-Calleros, C.; Rodríguez-Huezo, M.E.; Vernoncarbohydrate polymers. J Food Eng 77 (2006) 753-760

49. Qi, Z. H.; Xu, A. Starch-based ingredients for flavor encapsulation. Cereal Foods World 44 (1999) 460-465

50. Madene, A.; Jacquot, M.; Scher, J.; Desobry, S. Flavour encapsulation and controlled release - a review. Int J Food Sci Technol 41 (2006) 1-21

51. Righetto, A.M.; Netto, F.M. Vitamin C stability in encapsulated green West Indian cherry juice and in encapsulated synthetic ascorbic acid. J Sci Food Agric 86 (2006) 1202-1208

52. Desobry, S.A.; Netto, F.M.; Labuza, T.P. Comparison of spray-drying, drum-drying and freeze-drying for $\beta$-carotene encapsulation and preservation. J Food Sci 62 (1997) 1158-1162

53. Reinnecius, G.A.. Carbohydrates for flavor encapsulation. Food Technol 46 (1991) $144-152$

54. Igual, M.; García-Martínez, E.; Martín-Esparza, M. E.; Martínez-Navarrete, N. Effect of processing on the drying kinetics and functional value of dried apricot. Food Res Int 47 (2012) 284-290

55. Igual, M.; García-Martínez, E.; Camacho, M. M.; Martínez-Navarrete, N. Effect of thermal treatment and storage on the stability of organic acids and the functional value of grapefruit juice. Food Chem 118 (2010) 291-299 


\section{Highlights}

- Spray-drying lulo optimization according to inlet air temperature and solutes

- High nutritive and functional value, and lowest hygroscopicity and water content

- $125^{\circ} \mathrm{C}, 3 \%$ arabic gum and $13.4 \%$ maltodextrin were found to be the optimum conditions

- Inlet temperature had the lesser effect on the studied variables

- Solutes promoted fruit bioactive compounds retention during spray-drying 
Table 1. Matrix of the central composite design ( $\mathrm{x}_{\mathrm{i}}$ : independent variables) and experimental data obtained for the response variables studied $\left(\mathrm{Y}_{\mathrm{j}}\right)$

\begin{tabular}{ccccccccccccccc}
\hline Run & $\mathrm{X}_{1}$ & $\mathrm{X}_{2}$ & $\mathrm{X}_{3}$ & $\mathrm{Y}_{1}$ & $\mathrm{Y}_{2}$ & $\mathrm{Y}_{3}$ & $\mathrm{Y}_{4}$ & $\mathrm{Y}_{5}$ & $\mathrm{Y}_{6}$ & $\mathrm{Y}_{7}$ & $\mathrm{Y}_{8}$ & $\mathrm{Y}_{9}$ & $\mathrm{Y}_{10}$ & $\mathrm{Y}_{11}$ \\
\hline \hline 1 & 150 & 5 & 5 & 100 & 32 & 10 & 37 & 3 & 48 & 227 & 325 & 881 & 125 & 99 \\
2 & 150 & 5 & 5 & 97 & 42 & 10 & 38 & 4 & 40 & 223 & 319 & 881 & 131 & 100 \\
3 & 180 & 0 & 0 & 106 & 0.4 & 21 & 18 & 4 & 114 & 31 & 37 & 366 & 61 & 47 \\
4 & 150 & 5 & 5 & 101 & 34 & 10 & 37 & 3 & 35 & 234 & 366 & 924 & 124 & 100 \\
5 & 150 & 5 & 5 & 97 & 42 & 10 & 38 & 4 & 40 & 226 & 342 & 948 & 125 & 100 \\
6 & 180 & 10 & 10 & 108 & 35 & 7 & 61 & 0.9 & 47 & 215 & 358 & 813 & 120 & 85 \\
7 & 150 & 5 & 5 & 95 & 38 & 10 & 38 & 2 & 38 & 216 & 371 & 825 & 131 & 97 \\
8 & 150 & 5 & 5 & 98 & 42 & 10 & 38 & 4 & 39 & 223 & 378 & 860 & 125 & 101 \\
9 & 120 & 10 & 0 & 77 & 34 & 10 & 38 & 2 & 56 & 181 & 413 & 661 & 88 & 100 \\
10 & 150 & 0 & 5 & 91 & 20 & 14 & 27 & 4 & 55 & 186 & 362 & 848 & 100 & 71 \\
11 & 150 & 13.4 & 5 & 95 & 32 & 7 & 53 & 1.3 & 44 & 243 & 405 & 855 & 119 & 94 \\
12 & 200 & 5 & 5 & 115 & 34 & 10 & 36 & 2 & 60 & 193 & 354 & 744 & 91 & 76 \\
13 & 180 & 0 & 10 & 119 & 16 & 10 & 37 & 2 & 52 & 197 & 381 & 861 & 118 & 94 \\
14 & 120 & 0 & 0 & 77 & 9 & 21 & 19 & 7 & 82 & 41 & 48 & 644 & 87 & 71 \\
15 & 120 & 10 & 10 & 78 & 29 & 7 & 59 & 2 & 51 & 229 & 413 & 933 & 136 & 147 \\
16 & 100 & 5 & 5 & 67 & 27 & 10 & 37 & 4 & 56 & 205 & 362 & 819 & 113 & 97 \\
17 & 150 & 5 & 5 & 101 & 34 & 10 & 37 & 3 & 35 & 231 & 374 & 949 & 124 & 99 \\
18 & 180 & 10 & 0 & 106 & 42 & 10 & 37 & 2 & 50 & 175 & 370 & 814 & 101 & 95 \\
19 & 150 & 5 & 5 & 100 & 32 & 10 & 37 & 3 & 48 & 220 & 316 & 930 & 126 & 99 \\
20 & 150 & 5 & 0 & 95 & 19 & 14 & 28 & 5 & 52 & 152 & 355 & 700 & 90 & 72 \\
21 & 120 & 0 & 10 & 82 & 36 & 10 & 37 & 3 & 50 & 211 & 415 & 994 & 120 & 101 \\
22 & 150 & 5 & 13.4 & 93 & 30 & 7 & 55 & 1 & 44 & 242 & 412 & 890 & 128 & 92 \\
23 & 150 & 5 & 5 & 98 & 42 & 10 & 38 & 4 & 39 & 222 & 381 & 925 & 131 & 101 \\
\hline
\end{tabular}

$Y_{1}$ to $Y_{11}$ : response variables of outlet temperature $\left({ }^{\circ} \mathrm{C}\right.$ ), product yield ( $\mathrm{g}$ solutes in the powder/ $100 \mathrm{~g}$ solutes in the mixture), drying ratio (powder solid content/ feed solid content), productivity $(\mathrm{g} / \mathrm{h})$, water content $(\mathrm{g} / 100 \mathrm{~g})$, hygroscopicity $(\mathrm{g}$ water gain $/ 100 \mathrm{dry} \mathrm{solids})$, ascorbic acid content $(\mathrm{g} / 100 \mathrm{~g}$ TLS $)$, vitamin $\mathrm{C}$ content $\left(\mathrm{g} / 100 \mathrm{~g}_{\mathrm{TLS}}\right)$, total phenolic content $\left(\mathrm{g}\right.$ GAE$/ 100 \mathrm{~g}_{\mathrm{TLS}}$ ), total flavonoid content ( $\mathrm{RE} / 100 \mathrm{~g}_{\mathrm{TLS}}$ ) and antioxidant capacity (mmol TE/100g $\mathrm{g}_{\mathrm{TLS}}$ ), respectively.

$\mathrm{x}_{1}, \mathrm{x}_{2}$ and $\mathrm{x}_{3}$ independent variable of inlet temperature $\left({ }^{\circ} \mathrm{C}\right)$, arabic gum $(\mathrm{g} / 100 \mathrm{~g}$ pulp) and maltodextrin $(\mathrm{g} / 100 \mathrm{~g}$ pulp), respectively. 
Table 2. Regression coefficients and adjusted $R^{2}$ for the final reduced models

\begin{tabular}{|c|c|c|c|c|c|c|c|c|c|c|c|}
\hline $\begin{array}{l}\text { Regression } \\
\text { coefficient }\end{array}$ & $\begin{array}{l}\text { Outlet temperature } \\
\qquad\left(\mathrm{Y}_{1}\right)\end{array}$ & $\begin{array}{c}\text { Product yield } \\
\left(\mathrm{Y}_{2}\right)\end{array}$ & $\begin{array}{l}\text { Drying } \\
\text { ratio } \\
\left(\mathrm{Y}_{3}\right) \\
\end{array}$ & $\begin{array}{c}\text { Productivity } \\
\left(\mathrm{Y}_{4}\right) \\
\end{array}$ & $\begin{array}{c}\text { Water content } \\
\left(\mathrm{Y}_{5}\right) \\
\end{array}$ & $\begin{array}{c}\text { Hygroscopicity } \\
\left(\mathrm{Y}_{6}\right)\end{array}$ & $\begin{array}{c}\text { Ascorbic acid } \\
\left(\mathrm{Y}_{7}\right)\end{array}$ & $\begin{array}{c}\text { Vitamin C } \\
\left(\mathrm{Y}_{8}\right) \\
\end{array}$ & $\begin{array}{c}\text { Total } \\
\text { phenols } \\
\left(\mathrm{Y}_{9}\right)\end{array}$ & $\begin{array}{c}\text { Total } \\
\text { flavonoids } \\
\left(\mathrm{Y}_{10}\right) \\
\end{array}$ & $\begin{array}{c}\text { Antioxidant capacity } \\
\left(\mathrm{Y}_{11}\right)\end{array}$ \\
\hline \multicolumn{12}{|l|}{ Constant } \\
\hline $\begin{array}{l}b_{0} \\
\text { Linear }\end{array}$ & -38.0119 & 2.8869 & 18.2515 & 35.2978 & 9.1564 & 197.272 & -259.489 & 114.781 & -16.8269 & -67.0776 & 118.474 \\
\hline$b_{1}$ & 1.3052 & - & 0.0169 & -0.1134 & -0.0238 & -1.3052 & 4.1687 & - & 11.3169 & 2.1885 & -0.3275 \\
\hline$b_{2}$ & - & 5.3933 & -1.3506 & 1.63101 & -0.3105 & -7.324 & 21.9153 & 30.9427 & -41.1455 & 4.5094 & 2.3135 \\
\hline$b_{3}$ & - & 5.1108 & -1.0779 & -0.9649 & -0.2861 & -7.217 & 29.0628 & 31.7247 & 75.6376 & 7.2362 & 2.2676 \\
\hline \multicolumn{12}{|l|}{ Square } \\
\hline $\mathrm{b}^{2}$ & -0.0028 & - & - & - & - & 0.0042 & -0.0138 & - & -0.048 & -0.0079 & - \\
\hline$b_{2}^{2}$ & - & -0.1942 & 0.0286 & - & - & 0.3352 & -0.7902 & - & - & -0.2674 & - \\
\hline $\begin{array}{l}\mathrm{b}_{3}^{2} \\
\text { Interactions }\end{array}$ & -0.0771 & -0.1996 & 0.0389 & - & - & 0.2567 & -1.2078 & - & -3.3875 & -0.3537 & - \\
\hline$b_{12}$ & - & - & - & - & - & - & & - & 0.37 & - & - \\
\hline$b_{13}$ & - & - & -0.0034 & 0.0227 & - & - & & - & - & - & - \\
\hline$b_{23}$ & - & -0.3815 & 0.0905 & - & 0.0188 & 0.4516 & -1.2438 & -3.6147 & -2.8702 & - & - \\
\hline$R^{2}$ adj & 0.96 & 0.776 & 0.97 & 0.866 & 0.801 & 0.837 & 0.971 & 0.756 & 0.792 & 0.852 & 0.744 \\
\hline
\end{tabular}

$b_{i}$ : the estimated regression coefficient for the main linear effects. $b^{2}$ : the estimated regression coefficient for the quadratic effects. $b_{i j}$ : the estimated regression coefficient for the interaction effects. $i=1$ : Inlet temperature; $i=2$ : Arabic gum; i=3: Maltodextrin. 
